\title{
Legal Analysis of Unlawful Conduct in Online Transactions Based on Law No. 11 of 2008 concerning Information and Electronic Transactions
}

\author{
Stevanus Adrianto Passat ${ }^{1}$, Evita Isretno Israhadi ${ }^{2}$ \\ Borobudur University ${ }^{1,2}$ \\ \{stevunborr@gmail.com¹, evita_isretno@borobudur.ac.id² $\}$
}

\begin{abstract}
The use of the internet in human activities leads to an infinite state of the world. People in their daily lives widely enjoy using the internet. Still, the internet's existence does not escape from the various problems it causes, similarly, in business activities, which can be done online or known as ECommerce. In practice, this E-Commerce activity relates to agreements governed by civil law, and their implementation often poses problems that cause harm to others. Such actions are called unlawful acts. This action has been conventionally stipulated in Article 1365 Burgerlijke Wetboek (BW). Still, it is not explicitly regulated in Law No. 11 of 2008, whereas one of the legal provisions applicable in E-Commerce in Indonesia is the thematic law. This condition causes many losses caused by illegal acts in online business transactions, but Law No. 11 of 2008 has not been able to accommodate the problem.
\end{abstract}

Keywords: Consumer Protection; Electronic Transactions; Consumer

\section{Introduction}

Indonesia is currently carrying out national development in various fields with several targets to improve the results of such products for the community's welfare. Among the many federal development sectors, growth in the economic sector is one of the significant agendas and directly influences people's lives in Indonesia (Supriyanto, 2021). Trade is one of the areas that support economic activities in the community and affects the condition of the national economy. Trade is vital in improving sustainable economic growth, improving the implementation of national development to realize equitable development and its results, and maintaining national stability. One of the efforts that can be made to realize significant economic growth in the trade sector, especially in the era of globalization, is applying between trading systems and information technology.

Currently, the development and application of information technology in the economic sector have developed rapidly. The rapid growth and application of information technology have resulted in the more effortless flow of information that can be obtained by the public while making it easier for people to communicate with each other by crossing the boundaries of space and time. Globalization in the economic world, especially trade, is increasingly facilitated by the internet (Interconnected Networking) as a medium of fast communication. 
Trade transactions can be done directly or indirectly, in the sense of through the internet media (cyberspace). Trading transactions by utilizing internet means has transformed the business world from a traditional trading pattern into a more modern trading system, a virtual trading system known as Electronic Commerce. In its development, Electronic Commerce (ECommerce) was born in addition to the development of information technology and the demands of the public to fast-paced service, easy, practical, and want better quality.

Electronic trade transactions in Indonesia show rapid development. In this case, internet technology, primarily e-commerce, has a massive influence on global trade. The rapid growth of Electronic Commerce (e-commerce) is caused by several things, as follows:

a. Electronic Commerce can reach more customers, and at any time, customers can access all information continuously;

b. Electronic Commerce can encourage creativity from the seller appropriately and quickly, and the distribution of information delivered takes place periodically;

c. Electronic Commerce can create high efficiency, cheap, and information;

d. Electronic Commerce can improve customer satisfaction with fast, easy, safe, and accurate service;

Trade transactions over the internet are very profitable for many parties, so these trade transactions are in great demand, not only for manufacturers but also consumers. In general, Electronic Commerce has provided benefits both for consumers and for manufacturers. Electronic commerce consumers change the way consumers obtain the desired product, while for manufacturers, Electronic Commerce has facilitated the marketing process.

Although the use of the internet in trade transactions promises various conveniences, this does not mean Electronic Commerce is a system that is free from problems, especially for countries that have not set about Electronic Commerce. In practice, there have been many cases that harm consumers due to the use of internet media in these trade transactions (Sanusi, 2001). The issue is, for example, the default of the Business against its consumers in a trade transaction through the internet, in this case, the consumer has made payments through internet banking facilities to businesses, but companies do not send goods that have been purchased by consumers or enterprises mistakenly in sending the goods, so this is detrimental to consumers. Also, there are often actions that can be qualified as acts against the law.

Currently, in Indonesia, there is Law No. 11 of 2008 on Information and Electronic Transactions (in the future referred to as the ITE Law). In the ITE Law, there have been arrangements regarding electronic transactions, including internet trading, but often can not accommodate unlawful acts in electronic Commerce due to the broad scope of understanding of illegal acts that are not explicitly regulated or specifically in the ITE Law. The regulation on unlawful acts is only stipulated in Article $1365 \mathrm{BW}$, which requires interpreting the law in applying such provisions to illegal acts in E-commerce. Moreover, often acts against the law are directly considered a criminal act, causing difficulties in claiming material and immaterial losses. Criminal sanctions only provide corporal punishment and or fines whose purpose is to generate a deterrent effect to the perpetrator.

\section{Methods}

Research methods as an effective way of finding scientific truths are the author's concerning aspects of methods that include thinking to find a purpose. This type of research is development research with a descriptive approach. Furthermore, the method of procedure that the author uses is normative legal research that is legal research conducted by researching 
library materials or secondary data. The legal materials are organized systematically, reviewed, and then drawn a conclusion concerning the problem being examined.

In a study must be disclosed the type of data used is a type of secondary data where data obtained from sources whose data properties have been documented by other parties. Data collection for normative law research, writing use with literature study method. In this case, the author must be observant and precise to find the data in the legislation and in the literature that relates to the problem that the author examines. Researchers conduct data processing in a qualitative way that is a data analysis method that does not display numbers as a result of research but is presented in the form of discussion with a description of sentences and presented in writing.

\section{Discussion}

\subsection{Legal Review About Online Business Transactions}

The development of science and technology has a vast influence on every area of life, including the process of trade or trade transactions. There have been many trading transactions through electronic media known as E-Commerce, where the parties who want to make transactions do not have to be face-to-face but can be done under the condition that each party is in a different place. Trades like this are made through a system that is the internet, and it is not something new in society, including in Indonesia.

Speaking of the validity of a transaction electronically, it must first be affirmed the legal basis of the transaction referred to. Electronic transactions are born based on the principle of freedom of contract as stipulated in Article 1338 paragraph (1) BW, where everyone is free to determine the form, type, and content of the agreement/agreement as long as it remains in compliance with the terms of the validity of the Agreement per the provisions of Article 1320 BW, does not violate public order and decency, so that any agreement made by the parties becomes law for the parties who make it. Similarly, in electronic transactions, the parties involved in the transaction are the subject of law. Both persons and legal entities are free to make alliances with the form, manner, and content determined by the Agreement of the parties, in this case, the parties conduct a coalition in the form of transactions through the internet media with the contents of the Agreement agreed by the parties through the internet as well, so they are interconnected through the internet media.

According to the provisions of Article $1320 \mathrm{BW}$, the terms of validity of an agreement consist of the Agreement of the parties, the Proficiency of the parties, a sure thing, and a lawful cause. The Agreement of the parties means that there must be a conformity of will between the parties who make the Agreement either expressly or secretly. If an agreement arises due to coercion, error, or error, then the Agreement may be canceled, meaning that the Agreement is still valid until revoked by the judge at the parties' request. Thus this Agreement is one of the subjective conditions for the validity of the Agreement. Similarly, in electronic transactions, agreements occur after a contract from the parties to the transaction. Based on the consensual principle, the Agreement is considered to exist simultaneously as the onset of an agreement to ally. There are several theories about the deal, namely:

a. Listings theory (the theory of the birth of will), according to this theory, the Agreement occurs when the offer has been born of choice from the other party, and this will is said to exist at the time the other party begins to write a letter of acceptance, (Expedition Theory); 
b. Verzend theorie (the theory when sending a letter of receipt), according to this theory the Agreement occurs when the acceptance letter is sent to the Bidder, (Transmission Theory);

c. Onvangs theorie (the theory when receiving a letter of offer), according to this theory the Agreement occurs when the letter of receipt arrives at the address of the Bidder, (Reception Theory);

d. Vernemings theory (the theory of knowledge the letter of receipt), according to this theory, the new covenant occurs when the Bidder has opened and read the acceptance letter (Information Theory).

Meanwhile, the Viena Convention on International Sales of Goods (1988) has received Reception Theory. Based on Article 15 of the Uncitral Model Law on E-Commerce (1996), it is said that the place of validity of the message data sent or received, unless regulated differently, in this case, the delivery of news takes place in a place where the sender of the information has a legitimate area of Business ( place of Business) and received in a place where the recipient of the news has an honest place of Business. The appointment in the Uncitral Model Law 1996 was carried out considering electronic data exchange (electronic data interchange) following the method of business data exchange or standard trading with the format commonly agreed by the parties.

The Proficiency of the parties is a general requirement to be able to perform legal acts. When he has grown up, a person is said to be capable of law(rechtsbekwaamheid) is common sense and is not prohibited by the laws and regulations. According to Article 47 of Law No. 1 of 1974 concerning Marriage, an adult is 18 years old or has been married. Common sense means not mental cached, not a waste, and not under guardianship under Article 1330 jo 433 $\mathrm{BW}$. If the proficiency requirements that are also subjective terms are not met in an agreement, the Agreement may be canceled as described in the previous section. A capable of law (rechtsbekwaamheid) isn't necessarily authorized to do legal acts (rechtsbevoegheid). Thus rechtsbekwaamheid is a general requirement in doing legal actions, while rechtsbevoegheid is a unique condition.

Similarly, in an electronic transaction, the relevant parties must meet the needs of this skill. Still, in reality, the other party does not know whether the other party qualifies for Proficiency or not. Still, this electronic transaction must be based on an element of trust with each other.

A specific thing in the Agreement means the goods that become the object of an agreement that is tradable as stipulated in Article 1332 BW. According to Article $1333 \mathrm{BW}$, the goods that become the object of an agreement must be particular or at least must be determined type, while the amount does not need to be defined as long as it can then be selected or taken into account. Article 1334 paragraph (1) BW specifies that new items that will exist in the future can also be the object of the Agreement, while in Article 1334 paragraph (2) BW mentioned that the goods that will be in the inheritance of another person as the heir can not be used as the object of an agreement because it is considered a violation of decency unless previously the goods have been given by the prospective heir to his prospective heir. Agreements whose object violates the provisions of the above, as an objective condition for the validity of the Agreement then the Agreement null and void means that from the beginning the Agreement is considered never existed so that there is no basis to sue each other before the judge (court). In electronic transactions, the promised object must be transparent, both the type and the amount.

A lawful reason is another objective requirement for the validity of the Agreement. Under Article $1335 \mathrm{BW}$, an agreement without cause or made for wrong or prohibited basis has no power. 
In addition to the principle of freedom of contract, the law of Agreement in Indonesia recognizes several other directions, namely:

a. The principle of sensualism, which is to assume that the Agreement has existed for a moment after there is a consensus from the parties.

b. The principle of trust between the parties to bind each other in carrying out the covenant.

c. The principle of binding power, meaning that the parties are bound to the covenant's content and the principles of morals, decency, and habits.

d. The principle of legal equality, meaning that both parties are equally positioned before the law, must respect each other.

e. The principle of balance, meaning that the parties are obliged to carry out their respective obligations in good faith.

f. The principle of legal certainty can be seen from the provision that the Agreement made by the parties applies as law to its makers.

g. Moral Principle, meaning in carrying out the covenant, is based on morals as a call to conscience.

h. The decency principle outlined in Article 1339 BW states that the Agreement's content is not contrary to the prevailing laws and regulations, propriety, and decency.

i. The custom stipulated principle in Article 1339 jo $1347 \mathrm{BW}$ means that an agreement concerns matters that have been stipulated in the legislation and concerns traditions that are commonly followed.

Thus transactions conducted electronically are also tied to the principles as described above. In addition to the terms of the validity of the Agreement as described above, we must also know the elements of the Agreement according to the science of civil law, namely:

a. Essential elements, i.e., essential elements, must be present in an agreement, such as the parties' identity, Agreement in the Agreement.

b. Elements of natural, i.e., elements considered to have existed in the Agreement even if the parties do not specify expressly in the Agreement, such as good faith in the Agreement, there is no hidden cached in the object of the Agreement.

c. Accedentialia elements, i.e., elements added to the Agreement by the parties, such as the "purchased goods are non-refundable" clause.

The above elements must also be applied in an electronic transaction, meaning that the parties' identity must be clear. The Agreement must not occur legal defects meaning there should be no coercion, ignorance, and fraud. Transactions conducted electronically must be accompanied by good faith and trust between the parties, although this is not stated in the Agreement. Each transaction, including those made through electronic, can be determined extermination clause as part of the element accident described above.

Based on the development of information technology, business transactions can be done in real or conventional and through electronic media, in this case, the internet, which is known as e-commerce. Based on the provisions of Article 1, number (2) of Law No. 11 of 2008 concerning Information and Electronic Transactions (after this referred to as the ITE Law), it is stated that electronic transactions are legal acts conducted using computers computer networks and other electronic media. In line with this, an electronic transaction including electronic trade transactions must be entered into an electronic contract that binds the parties according to Article 18 of the ITE Law.

Electronic commerce transactions, as part of electronic Business, can be formulated based on e-commerce terminology. In general, e-commerce can be defined as any form of trade of goods and services using electronic media. In addition to the above mentioned, those business activities are part of business activities (e-commerce is apart from e-business). 
E-commerce transactions involve several parties, either directly or indirectly, including Merchants, Consumers or cardholders, Banks, Providers, and Certification Authorities.

Rayport and Jaworski argue that there are four categories of e-commerce applications, namely:

\section{a) Business to Business}

The Business to Business e-commerce app refers to the full spectrum of e-commerce that occurs between two companies. E-commerce business to Business includes activities such as buyers and sellers, supplier management, inventory management, channel management, payment management, as well as service and support, e-commerce Business to Business is spearheaded by Chemdex (www.chemdex.com), FastParts (www.fastparts.com), and FreeMarkets (www.freemarkets.com).

\section{b) Business to Consumer}

E-commerce Business to Consumer refers to the exchange that occurs between companies and consumers. The pioneers of the business-to-consumer e-commerce category include Amazon.com, Yahoo.com, and Schwab.com. The duplicate transactions as those that arise in e-commerce Business to Consumer also occur in this e-commerce business. These transactions include sales activities, consumer search and service, and support for consumers.

\section{c) Consumer to Consumer}

This Consumer to Consumer Exchange covers transactions that occur between and between consumers and consumers. Such exchanges may or may not involve third parties, resulting in auction exchanges through the eBay site.

\section{d) Consumer to Business}

In this consumer-to-business relationship, consumers can bind themselves together to form and establish themselves as a group of buyers for a company. In carrying out these activities, the consumers can be encouraged by economic orientation or by social direction.

Online business transactions (e-commerce) must be poured into a form of electronic contract as an embodiment of the principle of freedom of contract as stipulated in Article 1338 paragraph (1) BW. In this case, everyone has the freedom to make and determine the form, kind, and content of the Agreement. As long as it remains eligible for the Agreement's validity as stipulated in Article 1320 BW, it does not violate public order decency. Such contracts are binding and apply as law to the parties of their makers. According to Article 1 number (17) of the ITE Law, electronic contracts are agreements made through electronic systems. Meanwhile, based on Article 1 number (5) of the ITE Law, it is stated that electronic systems are a series of electronic devices and procedures that serve to prepare, collect, process, analyze, store, display, announce, transmit or disseminate electronic information, in this case, the internet.

In Article 1 number (1) of the ITE Law, it is explained that electronic information is one or a set of electronic data including but not limited to writing, sound, images, maps, designs, 
photos, electronic data interchange, electronic mail, telegram, telex, telecopy or the like, letters, signs, numbers, aliases codes, symbols or perforations that have a meaning or can be understood by people who can understand it. Looking at the above, of course, the instruments used and applicable in this online business contract are paperless things but still recognized the validity and have the same legal force as conventional contracts. Therefore, all legal actions and actions that occur in this online business contract must be considered because the legal consequences that arise have the same legal impact as conventional legal acts or in the real world.

Electronic business transactions involving instruments and legal actions in cyberspace and paperless nature gave birth to a proof system that is electronic as well. In general, the prevailing evidence in online business transactions based on electronic contracts refers to the evidentiary law as stipulated in Article 1865 and Article $1866 \mathrm{BW}$, which affirms the principle of proof that any person who feels he has rights or feels his rights are impaired, must be able to prove it legally. The evidence in question must follow the provisions of legally recognized evidence as affirmed in Article 1866 junto Article 164 HIR (Het Herziene Indonesisch Reglement), which consists of:
a. Proof of letter/written;
b. Witness evidence;
c. Evidence of conscience;
d. Proof of confession; Dan
e. Proof of oath

These evidence tools become evidence in proof of civil cases, including those related to contracts or agreements. Based on the provisions of Article $1865 \mathrm{BW}$ above, parties who feel they have rights or feel their rights are civilly impaired must be able to prove it by means and methods of proof that have been determined in the law of civil proceedings. However, this does not mean that the other party does not have the right to prove it, meaning that each party has the same rights in the evidentiary process. The order of evidence that can be submitted is mentioned in Article 1866 junction Article 164 HIR above, mutatis mutandis.

\title{
3.2 Unlawful Acts Based on Civil Law in Indonesia
}

Illegal acts(onrechtmatigedaad) are stipulated in Article 1365 of the Civil Code, which reads: Any unlawful act that brings harm to another person, obliging the person who for his fault to issue the loss, indemnify the damages. A person who is considered to have committed an act against the law may be penalized by reimbursing the victim for their guilt through a claim filed with a judicial institution or a dispute resolution institution outside the court. However, it must be proven and accounted for the existence of unlawful acts referred to through the evidentiary elements of this illegal act, which consists of:

\author{
a. Unlawful conduct \\ b. Error \\ c. Losses \\ d. There is a causal relationship between unlawful acts, mistakes, and losses that exist
}

Unlawful acts are considered to occur by seeing the actions of the perpetrators who are suspected of violating the law, contrary to the rights of others, contrary to the legal obligations of the perpetrator, contrary to decency and public order, or contrary to propriety in society both against themselves and others. However nevertheless, an act that is considered as an act against this law must still be accountable whether it contains an element of wrongdoing or not. Article 1365 of the Civil Code does not distinguish errors in the form of deliberateness (opzet- 
dolus)and errors in the form of less careful (culpa); thus, the judge must be able to judge and consider the severity of the mistakes committed by a person concerning this unlawful act, so that it can be determined fair compensation.

A person cannot be prosecuted for committing an act against the law if the action is done in an emergency / noodweer, overmacht, the realization of personal rights, because of staffing orders or misrepresented that can be forgiven. If the error element in an act can be proven, he is responsible for the losses caused by his actions. Still, a person is liable for losses caused by his faults and activities that contain mistakes committed by his dependents, items under his supervision, and his pets, as specified in Article 1366 to Article 1369 of the Civil Code.

Speaking of indemnity has been arranged in BW. Indemnification consisting of costs, losses, and interest. Costs are any expenses that the debtor has manifestly incurred. Loss is any loss due to the destruction or destruction of creditors' belongings due to the debtor's negligence. Compensation in the form of material and immaterial losses, usually loss is given in the form of money or goods. Still, this compensation can also be given in the form of recovery of something, and if this damage is not implemented, it can be demanded forced money / dwangsom. However, this forced money is not a form of compensation but only as reinforcement so that the settlement in question is carried out. Interest is any profit that is expected or has been taken into account.

Unlawful acts as stipulated in Article 1365 of this Civil Code may also be used as a basis to file damages for acts deemed illegal in the process of online business transactions ( $E$ Commerce), either done through litigation dispute resolution or the courts by filing a lawsuit, or settlement of disputes on anon-litigation or out-of-court basis, for example, employing negotiation, mediation, conciliation or arbitration.

\subsection{Legal Aspects of Unlawful Actions in Online Business Transactions Based on the ITE Law}

Unlawful acts in online business transactions (E-Commerce) are said to have occurred if there has been (completed) an act of one party that was deliberately done against the other party and as a result of his actions caused losses to the other party. Which activities are performed online or in cyberspace through electronic instruments/data, whether using information or electronic documents in various ways in cyberspace? The use of electronic data as a medium of delivery of messages/data so that it can be done sending and receiving information quickly and concisely, both in the form of analog and digital electronic data, under its understanding that E-commerce is a trading system that uses electronic mechanisms that exist in the internet network and becomes a new color in the business world electronically and online.

The occurrence of unlawful acts in online business transactions (E-Commerce) that cause losses above requires rules that will become the legal basis for the claim for damages. Burgerlijke Wetboek and the ITE Act have a crucial role in this regard because explicitly, the arrangement of indemnity claims due to unlawful acts in online business transactions ( $E$ Commerce) is not regulated in the legislation in Indonesia. Still, under the mandate of the Law of Justice, which states that judges are obliged to explore the values that live in the community so that there is no legal vacuum, it becomes a handle that judges can not reject any case that goes to court because there is no rule or incomplete rule.

Extensive interpretation of the law or expanding the meaning of the word in a piece of legislation is one way to solve it. Thus Article $1365 \mathrm{BW}$ can be used as the legal basis for claims for unlawful acts in online business transactions (E-Commerce), with the support of 
proof based on electronic data recognized as valid evidence as in the applicable event law in Indonesia, has been regulated in Article 5 of the ITE Law. Therefore, BW and the ITE Law play a role in facing obstacles related to claims for damages for unlawful conduct in online business transactions (E-Commerce) referred to.

\section{Conclusion}

The legal provisions on unlawful acts are stipulated in Article $1365 \mathrm{BW}$ and are not specified in Law No. 11 of 2008 concerning Information and Electronic Transactions. The requirements of Article $1365 \mathrm{BW}$ can be applied to cases of unlawful conduct in online business transactions (E-Commerce) to fill the legal void, which is done based on extensive interpretation of the law.

The emergence of obstacles to claims for unlawful indemnity in online business transactions (E-Commerce) can be resolved by fixing the E-Commerce agreement, must meet the terms of the validity of the Agreement as stipulated in Article $1320 \mathrm{BW}$ and does not violate public order and decency, must also be considered aspects of prudence when making this E-Commerce business agreement. However, damages arising from unlawful acts in $E$ Commerce can be prosecuted, taking into account the law of proof of such losses, both materially and immaterially.

\section{References}

[1] Anwar, N. S. (2019). Analisis Transaksi Digital Cryptocurrency Sebagai Investasi Global Dalam Perspektif Hukum Islam (Studi Kasus Dinar Dirham di Makassar).

[2] Gordon, J. M. (1998). Business Law: An Introduction. Business Law: An Introductionby TheBusinessProfessor.Com, 501(c), 428-431.

[3] Santiago, F. (2016). Bunga Rampai Catatan Hukum. Perpustakaan Nasional RI. Katalog Dalam Terbitan.

[4] Supriyanto, Eko Eddya. 2020. Eksistensi Nilai-Nilai Pancasila Dalam Kebijakan Ekonomi Indonesia. 1st ed. Malang: Literasi Nusantara.

[5] Supriyanto, E. E. (2021). Strategi Penerapan Kebijakan Sovereign Wealth Funds (SWFs) di Indonesia: Studi Literatur dan Studi Komparatif Oman. Jurnal Inovasi Ilmu Sosial Dan Politik (JISoP), 3(1), 10-21. https://doi.org/10.33474/jisop.v3i1.6959

[6] Nababan, K. N. N. (2019). Tinjauan Legalitas Transaksi Bitcoin di Indonesia. JuristDiction, 2(5), 1745-1764. 